\title{
Regulating The MARKet FOR Legal SERVICES
}

\author{
MiCHAEL J. TREBILCOCK ${ }^{*}$
}

The regulation of the provision of professional services should be viewed from a consumer protection or welfare rationale. The legal profession should devote fewer of its regulatory resources to input regulation and instead, focus more of its resources on output regulation. A bottom line, output-oriented regulatory regime is what the consumer welfare perspective demands. While there are numerous advantages to the self-regulation of the legal profession, this self-regulation should not be absolute. Rather than moving completely away from the notion of self-regulation or to a form of co-regulation, the current regulatory regime should be tempered with appropriate public accountability mechanisms.
La réglementation de la prestation de services professionnels devrait être considérée du point de vue de la protection du consommateur ou d'un bien-être. La profession juridique devrait consacrer moins de ressources réglementaires à la saisie de la réglementation et consacrer davantage de ressources à la production de réglementation. Du point de vue du bien-être du consommateur, il faudrait un régime de réglementation axé sur les résultats et la production. Bien que l'autoréglementation de la profession juridique présente de nombreux avantages, elle ne devrait pas être absolue. Au lieu de s'écarter de la notion d'autoréglementation ou d'une forme de coréglementation, le régime actuel devrait être assoupli au moyen de mécanismes d'imputabilité publique indiqués.

\section{TABLE OF CONTENTS}

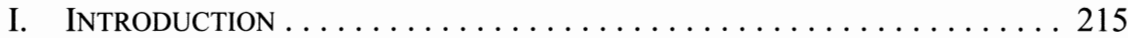

II. RATIONALES FOR PROFESSIONAL REgULATION . . . . . . . . . . 217

III. POLICY INSTRUMENTS FOR PROFESSIONAL REgULATION . . . . . . . . . . 219

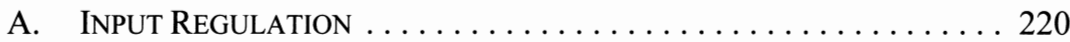

B. OutPut Regulation . . . . . . . . . . . . . . . . . . . . . . . 224

IV. Direct Versus Delegated Regulation $\ldots \ldots \ldots \ldots \ldots \ldots \ldots \ldots 227$

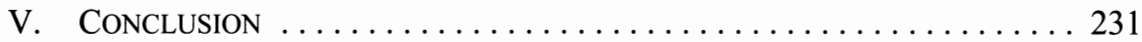

\section{INTRODUCTION}

The regulation of the professions has emerged as a major public policy issue in Canada and elsewhere over the past four decades. Major reviews have been conducted in Ontario on various aspects of the professions by the McRuer Royal Commission on Civil Rights, ${ }^{1}$ the Committee on the Healing $\mathrm{Arts}^{2}$ (the health professions), the Professional Organizations Committee $^{3}$ (law, accountancy, engineering, and architecture), and a Ministerial Review of the Regulation of the Health Professions, which led to the enactment of the Ontario Regulated Health Professions Act, 1991. ${ }^{4}$ In Quebec, the report of the Castonguay

* Chair in Law and Economics, Faculty of Law, University of Toronto. I am indebted to Lorne Sossin, Professor, Faculty of Law, University of Toronto, for invaluable comments on an earlier draft. Ontario, Royal Commission Inquiry into Civil Rights (Toronto: Queen's Printer, 1968). Ontario, Report of the Committee on the Healing Arts (Toronto: Queen's Printer, 1970). The Professional Organizations Committee, The Report of the Professional Organizations Committee (Toronto: Ontario Ministry of the Attorney General, 1980).

$4 \quad$ S.O. 1991 , c. 18. 
Commission on Professional Regulation in $1970^{5}$ led to the enactment of the Professional Code $^{6}$ in 1973, probably the most comprehensive regime of professional regulation to be found anywhere in the western world. Subsequently, the provinces of Alberta, Saskatchewan, and Manitoba undertook extensive reviews of their policies towards the professions. ${ }^{7}$ Beyond Canada, recent attempts by the British government ${ }^{8}$ and various state governments in Australia ${ }^{9}$ to reform the regulation of the legal profession, specifically by creating an independent oversight and complaints investigation agency, have generated intense controversy. ${ }^{10}$ In the United States, a more expansive application of antitrust law ${ }^{11}$ and constitutional guarantees of free speech (in the case of professional advertising and solicitation $)^{12}$ have subjected many of the practices of the established professions to enhanced judicial scrutiny. Both of these developments are also becoming increasingly evident in Canada. ${ }^{13}$ In Australia, the Trade Practices Commission (now the Australian Consumer and Competition Commission) has undertaken a review of a number of the restrictive regulatory

5 Quebec, Commission of Inquiry on Health and Social Welfare, Report of the Commission of Inquiry on Health and Social Welfare - The Professions and Society, vol. VII, Tome 1, Part 5 (Quebec City: Government of Quebec, 1970); see generally, Claude Castonguay, "The future of self-regulation: a view from Quebec" and René Dussault, "The Office des Professions du Québec in the context of the development of professionalism" in Philip Slayton \& Michael J. Trebilcock, eds., The Professions and Public Policy (Toronto: University of Toronto Press, 1978), 61 and 101, respectively.

$6 \quad$ R.S.Q., c. 43.

7 Alberta, Council on Professions and Occupations, Principles and Policies Governing Professional Legislation in Alberta (Edmonton: Council on Professions and Occupations, 1989); Saskatchewan, Towards the Development of a Professions Policy for Saskatchewan (Discussion Paper, 1990); Manitoba, Law Reform Commission, Regulating Professions and Occupations (Winnipeg: Queen's Printer, 1994).

$8 \quad$ Sir David Clementi, Review of the Regulatory Framework for Legal Services in England and Wales: Final Report (London: Department for Constitutional Affairs, 2004), online: Legal Services Review $<$ http://www.legal-services-review.org.uk/content/report/reportchap.pdf $>$..

9 Following a report by the New South Wales, Law Reform Commission, Scrutiny of the Legal Profession: Complaints Against Lawyers (Sydney: Law Reform Commission, 1993).

10 See W. Wesley Pue, "Death Squads and 'Directions over Lunch': A Comparative Review of the Independence of the Bar" in Law Society of Upper Canada, In the Public Interest: The Report and Research Papers of the Law Society of Upper Canada's Task Force on the Rule of Law and the Independence of the Bar (Toronto: Irwin Law, 2007) 175.

1 See e.g. National Society of Professional Engineers v. United States, 435 U.S. 679 (1978); Goldfarb v. Virginia State Bar, 421 U.S. 773 (1975).

12 See e.g. Bates v. State Bar of Arizona, 433 U.S. 350 (1977); Virginia State Board of Pharmacy $v$. Virginia Citizens Consumer Council, Inc. 425 U.S. 748 (1976); Bigelow v. Virginia, 421 U.S. 809 (1975); see generally Fred S. McChesney, “Commercial Speech in the Professions: The Supreme Court's Unanswered Questions and Questionable Answers” (1985) 134 U. Pa. L. Rev. 45.

13 Prohibition orders under the federal Competition Act, R.S.C. 1985, c. C-34, have been issued against local groups of lawyers and real estate associations for setting minimum fees for prescribed categories of services. Investigations against pharmacy and land surveying associations for price setting have also been undertaken. In the case of restrictions on professional advertising, the Supreme Court of Canada held in Rocket v. Royal College of Dental Surgeons of Ontario, [1990] 2 S.C.R. 232, that such restrictions may infringe s. 2 (freedom of expression) of the Canadian Charter of Rights and Freedoms, Part I of the Constitution Act, 1982, being Schedule B to the Canada Act 1982 (U.K.), 1982, c. 11. On professional advertising, see generally Albert J. Hudec \& Michael J. Trebilcock, "Lawyer Advertising and the Supply of Information in the Market for Legal Services" (1982) 20 U.W.O. L. Rev. 53. 
practices of various professions under Australian competition legislation, ${ }^{14}$ and the Canadian Competition Bureau has recently published a similar review. ${ }^{15}$

\section{Rationales for Professional Regulation}

Before we can sensibly address the role for professional regulation, it is crucially important to be clear on what the rationales are for regulating the provision of professional services at all (whomsoever by - a question deferred until later in this article). The only normative reference point that is defensible is a consumer welfare perspective. That is to say, if we ask of any set of policy choices, which one is likely to maximize net consumer welfare? This obviously entails balancing the benefits to consumers against both the public costs of administering the regulatory program in issue and the private compliance costs faced by those being regulated. While this may seem a trite observation, in many fields of economic regulation there have been long-standing controversies over exactly whose interests the policies in question are designed to serve. These controversies also arise in the area of professional self-regulation, where there have often been ambiguities as to whether the purpose of self-regulation is to promote the interests of the profession itself and members thereof(a professional protectionist rationale), or to advance the interests of the public whom the profession and its members serve (a consumer protection rationale).

With this consumer welfare perspective in mind, it is useful to identify which forms of market failure, in the absence of regulation, would be likely to jeopardize the welfare of consumers of professional services or other parties. The two most common forms of market failure in unregulated professional service sectors are: (1) information imperfections, and (2) externalities. With respect to information failures, consumers of professional services, including legal services, may be ill-equipped to diagnose or identify the precise nature of the problem or need they are confronting, which may require professional services. Even if they can identify the problem or need, they may be ill-equipped to choose an appropriate service provider, to exercise meaningful judgment over the appropriate service procedure, and to monitor effectively performance by the service provider of the relevant procedure thereafter and the time and costs associated therewith. With respect to externalities or involuntary third party effects, even if one assumes fully-informed consumers and providers, it may be that their contractual relationship generates an involuntary external cost for third parties, which the contracting parties have little or no incentive to internalize. In the case of professional service sectors, information imperfections are likely to loom large, justifying regulation in professions like law, medicine, and dentistry, where there are large ill-informed consumer populations on the demand side of the market. In the case of professions like engineering, architecture, and accounting, the justification for regulation is likely to rest much more strongly on third party effects. In the first two cases, for example, third parties are put at risk by dangerous design or construction practices, and in the third case, third parties may rely to their detriment on improperly prepared or audited financial statements. In the case of the legal profession, externalities may also arise, for example, in the case of an improperly drawn

14 Austl., Regulation of Professional Markets in Australia: issues for review: a discussion paper (Canberra, A.C.T.: Trade Practices Commission, 1990).

15 Competition Bureau, Self-regulated professions: Balancing competition and regulation (Gatineau, Que.: Competition Bureau, 2007). 
will, an improperly conducted custody dispute, or an incompetently argued case that yields an undesirable legal precedent. However, the principal market failure is likely to take the form of information asymmetries between providers and purchasers of legal services. ${ }^{16}$

One should be cautious, however, about over-generalizations. Large business clients, predominantly located in urban centres, appear to have no major information problems in making appropriate selections of lawyers for particular legal functions. Such clients tend to be repeat and sophisticated users of legal services and they (increasingly with the assistance of in-house counsel $)^{17}$ develop the experience required to make appropriate selections of legal services and to assess the quality of service being received. Informal communication networks through professional, business, and social contacts, also appear to provide quite reliable information about firm and lawyer expertise. Moreover, on the supply side of this segment of the legal services market, firms tend to be large and to have substantial amounts of firm-specific reputational capital at stake. ${ }^{18}$ They also adopt organizational structures that entail substantial forms of internal checks and balances on service quality. The second client sector that may not face major informational problems in choosing legal firms or lawyers appropriate to its needs consists of individuals and small business clients residing in smalland medium-sized communities. Here again, informal community information networks seem to be fairly efficient in disseminating information about the comparative costs and quality of available law firms and lawyers (although in very small communities consumers may face a lack of realistic choices). Furthermore, the legal functions that are typically to be performed in this setting tend to be less complex than those entailed in servicing the legal needs of large business clients. A third sector of potential clients of lawyers is comprised of individuals (households) and small businesses located in large town or urban settings. This urban small client sector may lack the benefit of the informal community networks that operate in small towns. It also may lack the sophistication and experience possessed by large business clients and hence is likely to face significant information problems. To the extent that this sector deals with smaller law firms or solo practitioners that lack effective internal quality assurance mechanisms and do not have significant amounts of firm-specific reputational capital at risk from effective client information networks, quality assurance problems are likely to be exacerbated.

All of this is to say that as a matter of a priori hypothesis, which should be tested against systematic empirical evidence (a point to be discussed below), a rough set of criteria that will indicate where quality control problems are likely to be most severe can be developed by reference to the type of client, the type of service provider, and the type of legal service. This narrowing or sharpening of the focus of quality control is important in developing a set of

16 For extensive economic critiques of imperfections in the operation of markets for legal services, see Gillian K. Hadfield, "The Price of Law: How the Market for Lawyers Distorts the Justice System" (2000) 98 Mich. L. Rev. 953; Gillian K. Hadfield, "Legal Barriers to Innovation: The growing economic cost of professional control over legal markets” (2008) 60 Stan. L. Rev. 101.

17 See Ronald J. Gilson \& Robert H. Mnookin, "Sharing Among the Human Capitalists: An Economic Inquiry into the Corporate Law Firm and How Partners Split Profits”(1985) 37 Stan. L. Rev. 313 at 38189.

18 Ibid.; Larry E. Ribstein, "Ethical Rules, Agency Costs, and Law Firm Structure” (1998) 84 Va. L. Rev. 1707. 
priorities for regulating post-entry competence. The section below reviews the principal forms of input and output regulation of the quality of legal services.

\section{Policy Instruments for Professional Regulation}

A range of regulatory instruments are available and widely invoked as a means of providing quality assurances in the professions. These regulatory instruments will be broadly categorized as either involving input regulation or output regulation. By input regulation, I mean the regulation of various dimensions of academic qualifications, practical skills training, on-the-job experience, or concentrated or specialized practice orientation. By output regulation, I mean the regulation that focuses on the quality of services actually delivered by a professional in a given context, abstracting from what educational, training, or experiential inputs she brings to the particular service being rendered.

The category of input regulation consists of such instruments as licensure, certification, specialty certification, mandatory continuing professional education, and mandatory requalification. The output regulation category consists of such instruments as civil liability, regulatory standard-setting and enforcement, and disciplinary processes, which may in turn fall into one of three categories: "misconduct," "passive competence," or "active competence" orientations. ${ }^{19}$ The misconduct orientation tends to focus on manifestations of lack of integrity or honesty, or other forms of unethical behaviour. The passive competence orientation focuses primarily on grosser forms of incompetence in cases that come to the attention of the disciplinary agency through means other than an active search for such deficiencies by the agency. The active competence orientation implies that the promotion of competence is a major objective of the discipline process and is proactively pursued by a variety of strategies designed to identify and eradicate cases of incompetence.

Regulating competence in any profession, including the legal profession, is likely to entail a mix of these instruments. This article argues that self-governing professions generally, and the legal profession in particular, in choosing the relative balance between input and output forms of regulation, have historically placed too much emphasis on input regulation and too little on output regulation. With respect to output regulation, they have adopted principally a misconduct orientation and neither a passive nor (preferably) an active competence orientation. This argument reflects parallel arguments made in other regulatory contexts around the world and is part of a more general regulatory reform movement that tends to stress the superiority of performance standards over design or process standards (for example, in product safety regulation) and output rather than input regulation (for example, in environmental policy through the use of pollution taxes or tradable pollution permits). 


\section{A. INPUT REGULATION}

\section{LICENSURE OR CERTIFICATION}

At the point of entry into a profession, two regulatory options are open: a certification regime or a licensure regime. A certification regime certifies or designates individual professionals who have acquired requisite training inputs but does not preclude uncertified professions from competing in the same market. An example of a form of certification regime is that pertaining to public accountancy in many provinces of Canada (including Alberta but not Ontario) where different classes of accountants with different designations compete amongst each other in the provision of public accountancy services. In contrast, a licensure regime precludes unlicensed professions from competing in the same service sector. A certification regime is designed to ameliorate information imperfections in a market. However, it is unlikely to be responsive to many forms of externalities and, even in relation to information imperfections, in many contexts may make unrealistic assumptions about the ability of consumers of professional services to make informed judgments about quality differences implicit in different certification regimes and between certified and uncertified professionals.

A licensure regime may be responsive to both information imperfections and externalities, but entails off-setting social costs in terms of restrictions on entry and perhaps reduced competition, dynamism, and innovation in the licensed domain. Licensure regimes also inherently entail drawing rather arbitrary and imprecise boundaries (horizontal, for example lawyers and accountants, and vertical, for example lawyers and paralegals) between providers of cognate professional services, which are difficult to justify and enforce in a principled way. Moreover, a licensure regime assumes that by prescribing a given set of educational and other inputs as a condition for licensure, the public can properly treat the ability of a practitioner to satisfy these requirements at the point of entry into a profession as a reasonable assurance in itself of his or her ability thereafter to provide the desired quality of service in all the service contexts covered by the licence. While this correlation may hold reasonably well for some practitioners' services, it is unlikely to hold for all practitioners in relation to all services at any time thereafter that are undertaken by them. Thus, a general licensure regime sends out an extremely fuzzy quality signal to potential consumers of professional services. ${ }^{20}$

Experience with licensure in the medical profession may be instructive. While licensure (as in other professions) is heavily based on student performance, empirical studies cast doubt about the extent to which academic success is an accurate predictor of practice performance. Roughly one-quarter of all state medical boards in the United States do not think that medical examinations screen out inept practitioners, and a former American Medical Association president has commented that most board-prepared examinations "offer few clues to a physician's competence to practice medicine." ${ }^{21}$ Most examinations involve

Michael J. Trebilcock, "Regulating Service Quality in Professional Markets" in Donald N. Dewees, ed., The Regulation of Quality: Products, Services, Workplaces, and the Environment (Toronto, Butterworths, 1983) 83.

21 Daniel B. Hogan, "The Effectiveness of Licensing: History, Evidence, and Recommendations" (1983) 7 Law \& Human Behav. 117 at 122. 
written responses to questions that require recall of facts that may or may not be related to good practice. Indeed, research in medicine suggests that academic grades predict little but future grades, while one study found almost no correlation between the practices of a group of 500 physicians and their performance in formal education programs. ${ }^{22}$

As a self-interested educator, I hope that similar empirical studies in law would not reveal such a weak correlation between student performance and subsequent effectiveness as a practitioner, but at this point we simply do not know. In any event, even if in law the correlation between student performance and subsequent success as a practitioner is higher than appears to be the case in medicine (at least in the U.S.), the correlation is still unlikely to be perfect. That is to say, some good students will not be successful practitioners; some poor students who nevertheless meet academic and licensing requirements may be successful practitioners; and the worst case (most plausible) scenario is that some poor students who nevertheless are marginally able to satisfy academic and other entry requirements are disproportionately represented among execrable practitioners and are not effectively screened out of the profession by point-of-entry controls. A further and important scenario is that lawyers who begin their careers as competent practitioners may allow their human capital to depreciate over time, develop bad practice habits, become over-committed, or be induced to stray into areas of practice beyond their competence.

This might suggest that the legal profession would be wise not to over-invest public and private resources in fine-tuning entry controls, which at best can merely cut off the tail of the competence distribution (eliminate outliers). For example, rather than prescribing completion of a Bar Admission program administered by law societies, might there not be a case for adopting the U.S. model and requiring applicants for entry into the legal profession to complete their academic training at an accredited law school and pass a practical knowledge, skills-oriented bar examination, leaving it up to students to determine how best to prepare for this examination? In this respect, it is notable that the Law Society of Upper Canada (LSUC) has now largely abandoned the Bar Admission Course and since 2006 administers licensure exams. It may make sense for law societies in Canada to follow the U.S. model and abandon a requirement of articling, but perhaps substitute instead a requirement that no licensee may practice on his or her own as a solo practitioner without first having spent, for example, one or two years working as an employee or partner of a practitioner who would be required to have, for example, at least six years' experience, and would be jointly and severally liable for deficiencies in performance by the new entrant, hence having significant incentives to monitor the quality of services rendered by the new entrant.

In recognition of the limitations of point-of-entry licensure controls, many professions, including the legal profession, have struggled with various regulatory options for controlling post-entry competence. Many of the most commonly preferred options entail further forms of input regulation. 


\section{SPECIALTY CERTIFICATION}

In the legal profession (and other professions) where a very wide range of highly specialized professional functions are performed, a single track or generic licensing regime standing alone is likely to produce a set of skills that is unevenly matched to the specialized functions many professionals will be called upon to perform in the course of their subsequent careers. Therefore, licensing requirements are weak guarantors of specialized professional competence. Hence a case is often made for some form of specialty certification in order to reduce the information asymmetries between providers and purchasers of professional services. At least in regard to law, one can be skeptical of the wisdom of devoting scarce regulatory resources (both public and private) to ambitious specialty certification programs, for the following reasons. First, there will be pressures for the proliferation of specialty classes as members of the profession strive to differentiate their services from others and thus attempt to reap whatever competitive advantage is associated with real or imagined service differentiation. Second, there will be disputes within the profession over the appropriate specification and boundaries of each specialty, over the appropriate criteria by which one is judged to be a specialist, and over the even-handedness and competence with which the plans are being administered, particularly if their administration primarily resides in the hands of those already certified as specialists. Third, a substantial amount of the scarce regulatory resources of the profession is likely to be invested in supporting the plans under the weight of these pressures. Fourth, plans that start off only as specialty certification programs are likely over time to become, at least in part, de facto specialty licensing programs, as those successful in having themselves certified as specialists then succeed in establishing exclusive claims to specialized competence (for example, by persuading large institutional employers or various demand-side regulatory agencies, legal aid administrators, etc., to stipulate specialty certification as a necessary qualification for undertaking particular professional functions or categories of work).

These developments are likely to lead, on the one hand, to a very extreme form of segmentation of professional service markets with a concomitant loss of mobility of human resources within those markets and, on the other hand, to a major new demand on the scarce regulatory resources of the governing bodies of the profession. As noted above, the information failures in the legal services market are probably relatively narrowly focused and do not require an ambitious across-the-board specialty certification regime. Further, the specialty certification program introduced by the LSUC in 1986, as of 2000, had attracted the participation of only 2.7 percent of practising lawyers in the province ( 625 out of 23,000$)$ and generated significant operating financial deficits for the Law Society in most years of its operation. ${ }^{23}$ Does the program in its present form or any imaginable revised form really serve an important quality assurance function for providers and purchasers of legal services? Instead of a formal specialty certification program, it would be preferable to permit law firms and individual lawyers to advertise freely relevant and accurate professional information about themselves, including, for example, areas of practice upon which they principally concentrate (without implying specialty recognition or accreditation), membership in the American College of Trial Lawyers, completion of full-time or part-time specialized LL.M. programs, etc. 


\section{MANDATORY CONTINUING EdUCATION ANd PERIODIC RE-QUALIFICATION}

It would be both unfair and inefficient to require all members of the legal profession to undergo periodic re-examination or participation in mandatory continuing education programs when there is no evidence that the vast majority of members of the profession require any such inducements to maintain their competence or even that they would benefit from such programs. Obviously, professionals maintain their competence in a wide variety of ways. The efficacy and choice of methods will vary considerably from individual to individual. To require all members of a profession to take periodic learning or relearning processes as rigid as either examinations or mandatory education courses seems to entail a serious misallocation of resources and to be vastly over-inclusive. To imagine imposing such requirements on, for example, the late John J. Robinette (or anyone's most admired lawyer) seems bizarre. I appreciate that current law society mandatory re-qualification proposals are much more narrowly and legitimately focused on members who have not been engaged in active practice for an extended period of time. However, mandatory re-qualification or reexamination proposals are often much more sweeping than this.

The logistical problems of generalized mandatory re-qualification or continuing legal education requirements are likely to be intractable, and the costs both explicit and implicit (in the form of the opportunity costs of professional time) are likely to be formidable. These costs could only be defended by a compelling demonstration of widespread incompetence throughout an entire profession. But if such evidence were available, which is not the case in the legal profession, it would make out a case for radical revision of entry standards rather than an attempt to redress these generalized shortcomings through any form of post-entry input regulation such as is entailed in periodic re-examination or mandatory continuing education requirements. This is not to say that re-examination or mandatory continuing education does not have a place in the regulation of professional competence. As will be argued below, that place is among a range of sanctions available to the disciplinary agency of the profession in responding to particular instances of incompetence.

The efficacy of continuing professional education has been studied more extensively in the medical profession than in the legal profession. Evidence of its utility in the medical profession in promoting competence is decidedly mixed. Studies have concluded that formal continuing medical education (CME) courses do produce knowledge transfer, but without reinforcement, feedback, or other behaviour modification techniques, ${ }^{24} \mathrm{CME}$ courses often do not produce positive outcomes in terms of improved physician performance or competence. In particular, studies suggest that mandatory programs that allow physicians to choose their own fields of study are onerous and wasteful. ${ }^{25}$ However, there is some evidence of the success of CME where education is targeted to specifically identified problems. For example, one study demonstrated significant improvement in physician performance where

24 Robert H. Brook, Rudolf L. Brutoco \& Kathleen N. Williams, "The Relationship between Medical Malpractice and Quality of Care" (1975)6 Duke L.J. 1197 at 1226; Gary L. Gaumer, "Regulating Health Professionals: A Review of the Empirical Literature" (1984) 62 Milbank Memorial Fund Quarterly 380 at 399-400; D.A. Davis et al., "Attempting to Ensure Physician Competence (1990) 263 Journal of the American Medical Association 2041 at 2041.

25 John C. Sibley et al., “A Randomized Trial of Continuing Medical Education” (1982) 306 New England Journal of Medicine 511. 
persistent use of $\mathrm{x}$-ray pelvimetry - a procedure that may cause harm to a fetus and for which there is little evidence of efficacy - was specifically targeted to reduce use. After an education program that discussed acceptable indications for the use of $\mathrm{x}$-ray pelvimetry, physicians with delivery privileges at the hospitals that participated in the program performed pelvimetry less than one-third as often as the physicians at hospitals that had not participated in the program. ${ }^{26} \mathrm{~A}$ survey of $50 \mathrm{CME}$ trials concluded that programs that use practice enabling or reinforcing strategies do consistently improve physician performance. ${ }^{27}$ These findings support the conclusion that effective practice modification requires that educational programs focus on specific problem areas and that the only demonstrably reliable way to remedy deficiencies is through the use of output monitoring followed up by corresponding deficiency-oriented training.

\section{B. OUTPUT REgULATION}

\section{Liability FOR Professional NegligeNCE}

The civil liability regime has some strengths as a response to quality control problems in that it focuses on outcomes. If a service fails to achieve the purpose for which it was reasonably intended and this is a result of negligence in its provision, liability arises. Liability serves both compensatory and deterrent functions. However, in many contexts the civil liability system will not well serve its compensatory or deterrent objectives, particularly in the segment of the legal services market where information asymmetries are likely to be most acute. Because the system is victim-initiated, it makes tenuous assumptions about a victim's ability to obtain and analyze the kind of information she needs in order to know that victimization has taken place. The client will only be able to resolve this information problem either by (1) mustering sufficient personal expertise to make a judgment on the matter (in which case she should consider switching sides in the marketplace), or (2) purchasing the advice of a second expert to pass judgment on the quality of performance of the first expert with a view to persuading a third expert (a judge) that the second expert is right. For these reasons, I assign very limited weight to civil liability as a form of output regulation of postentry competence.

\section{REGULATORY STANDARD-SETTING}

It is clear that in many professional contexts, the ability of a regulator to prescribe desired service characteristics or outcomes is closely circumscribed once it is recognized that many professional services may be unique because they are tailored to a particular client's personal needs or circumstances. Thus, most professions, including particularly the legal profession, have made very limited efforts to formulate and enforce required standards of conduct and performance in particular professional contexts. However, there are exceptions to this generalization. For example, in the building design and construction fields, the Ontario

27 D.A. Davis et al., "Evidence for the Effectiveness of CME: A Review of 50 Randomized Controlled Trials" (1992) 268 Journal of the American Medical Association 1111. 
Building Code Act, $1992^{28}$ and the Planning $A c t^{29}$ confer extensive powers on municipalities to prescribe structural, aesthetic, and other standards for new buildings. In the case of chartered accountants, the Canadian Institute of Chartered Accountants Handbook, ${ }^{30}$ to which members are required to adhere, sets out detailed audit and other accounting standards. Indeed, the Canada Business Corporations Act $^{31}$ requires that the handbook's standards be followed for audits required under the $A c t$, even when they are performed by someone other than a chartered accountant.

While the inherent difficulties of formulating performance standards across a broad sweep of professional services are acknowledged, much more could be done by the legal profession in this respect than has been done in the past, particularly in areas of professional practice where systematic patterns of practice deficiencies have been revealed, for example, through discipline complaints or errors and omissions claims.

\section{THE DisCIPLINARY PROCESS}

As noted above, the orientation of professional disciplinary processes can be characterized as falling predominantly into one of three categories: "misconduct," "passive competence," or "active competence" orientations. It is a fair generalization that disciplinary processes in the legal profession (and indeed in many other professions) overwhelmingly fall into the misconduct orientation category, only marginally engage a passive competence orientation, and have almost entirely rejected an active competence orientation. A review of formal disciplinary proceedings before law societies across Canada over the last number of years would likely reveal that these processes overwhelmingly focus on cases of dishonest or unethical behaviour ${ }^{32}$ or the most egregious forms of professional delinquency, and not on failures to meet acceptable standards of professional competence.

This is markedly less true in other professions such as public accountancy and medicine, although the experience of the medical profession is instructive in this respect. Despite various estimates that between 2 percent and 10 percent of all U.S. physicians are unscrupulous, unethical, delinquent, or incompetent, various studies have found that disciplinary action by state medical boards is almost insignificant in terms of the universe of practising physicians, targeting only a small fraction of 1 percent of all licensed physicians in any year. ${ }^{33}$ Moreover, disciplinary actions are generally related not to competence but to other aspects of professional ethics, such as drug-related offences, criminal charges, sexual

S.O. 1992 , c. 23.

R.S.O. 1990 , c. P.13.

(Toronto: Canadian Institute of Chartered Accountants, 1986).

R.S.C. 1985, c. C-44; Canada Business Corporations Regulations, 2001, S.O.R./2001-512, as am. by S.O.R./2003-317, ss. 71, 71.1.

Although Philip Slayton argues that the law societies have not done a very good job of even this: see Philip Slayton, Lawyers Gone Bad: money, sex and madness in Canada's Legal Profession (Toronto: Viking Canada, 2007).

Sylvia Law \& Steven Polan, Pain and Profit: The Politics of Malpractice (New York: Harper \& Row, 1978) at 43-44; U.S. Department of Health, Education and Welfare, Report on Licensure and Related Health Personnel Credentialing (Washington, D.C.: U.S. Government Printing House, 1971), cited in Hogan, supra note 21 at 124. 
impropriety, or abetting unlicensed persons to practice medicine. ${ }^{34}$ Nevertheless, in many institutional (primarily hospital) settings in recent years in the U.S. and Canada, much more systematic quality assurance and risk management programs have been instituted that increasingly and proactively monitor the quality of medical care by drawing on medical audit, utilization review, tissue and death review, and incident reports as triggers for more systemic reviews and corrections of practice deficiencies. ${ }^{35}$

The legal profession must move aggressively in a similar direction. After all, consumers of legal services are not interested in the quality of service inputs per se, but only the quality of service outputs. This, for most consumers, is properly their bottom line (as in other product and service markets). In short, a more targeted, bottom line, output-oriented regulatory focus is needed, because that is what a consumer welfare perspective demands, particularly in segments of the legal services market that are particularly afflicted by information asymmetries.

Let me sketch what such a strategy might entail. First, at a minimum, law societies should expand the range of sources they draw upon for problem identification to include: written or oral complaints about competence received by law societies; claims or complaints received by the Errors and Omissions Insurance Plan; complaints received from courts, taxing officers, or administrative agencies; and, ideally, reporting obligations placed upon lawyers with respect to serious lapses of competence that they have encountered with other lawyers.

It is particularly important that more effort be made to harness institutional intelligence and expertise about both individual and systemic practice deficiencies in legal practice (in much the same way that institutional quality assurance has developed in the hospital sector in the medical profession). Such an approach would still primarily engage the passive competence orientation in that it would be complaint-driven, albeit by a wider array of complaints. However, upon receipt of such complaints, particularly anything that resembles a pattern of complaints with respect to a particular practitioner, law societies should respond in much the same way as they do now to what may be perceived as the possibility of a pattern of financial irregularities (a "tip of the iceberg" phenomenon) and initiate some form of peer review or practice audit not only of the specific complaints received, but also of the practice of the lawyer in question more generally (as important 1999 amendments to the Ontario Law Society $\mathrm{Act}^{36}$ now contemplate). Courts, administrative agencies, and the Errors and Omissions Insurance Plan, beyond reporting patterns of complaints against particular practitioners, should also be encouraged or induced to identify more systemic patterns of professional deficiencies in particular areas of practice.

In the event that this information suggests that combinations of particular kinds of clients, particular kinds of legal practitioners, and particular kinds of legal services are high-risk in terms of competence, the law societies should undertake random practice audits of law firms or lawyers that fall within this high-risk profile. Consequential legislative modification to 
solicitor-client confidentiality rules should permit peer reviews of this kind (as of course is already possible with respect to financial audits). This strategy would begin to engage seriously the active competence orientation perspective that is referred to above. In addition to random practice audits of professionals practising in high-risk practice areas, it may also be desirable to have the legal ability to insist that practitioners in these high-risk areas participate in mandatory continuing legal education programs that are addressed specifically to identified systemic practice deficiencies in these areas. The inducement to participate may take the form of substantial errors and omissions risk premiums for practitioners in these areas who do not choose to participate in such programs.

As 1999 amendments to the Ontario Law Society Act now commendably recognize, in order to effectuate this more proactive competence orientation of the disciplinary processes of law societies, it is important to broaden the array of sanctions available to law societies. With the expanded focus on competence advocated in this article, the essentially punitive nature of traditional sanctions (that is, disbarment or suspension), is far too narrow, blunt, cumbersome, and penal to be responsive to many competence problems for which a more remedial or corrective approach is appropriate. Hence, remedial orders for practitioners found to be deficient in some set of practice skills might take the form of any of the following:

(1) mandatory legal education requirements that focus specifically on these areas of practice deficiency;

(2) mandatory re-qualification;

(3) confining a lawyer's practice to established areas of expertise and hence restricting her ability to practice outside these areas of expertise if competence problems have been revealed in other areas;

(4) requiring a practitioner to practice in an employment or partnership relationship with another lawyer so that joint and several liability creates incentives for the latter to monitor the quality of services of the former; or

(5) mandatory treatment programs for lawyers afflicted by substance abuse or psychological problems.

\section{Direct Versus Delegated Regulation}

Even if one were satisfied that the case was made for some combination of input and output regulation in a professional services market, one would still be faced with the question of how regulation should be administered. Since such powers are regulatory powers, one might expect that, whatever the appropriate regulatory response, the regulation of provider activities would be undertaken by public authorities. Indeed, delegated self-regulation is relatively exceptional and is accorded to a relatively small number of occupational groups or professions. For example, the big five Canadian banks (or other highly concentrated industries) have not been accorded substantial self-regulatory powers over their industries (presumably because this would entail significant risks of anti-social forms of collusion or cartelization). Equally, used car dealers, door-to-door salespeople, and telemarketers have 
not been accorded self-regulatory authority (presumably because they lack a settled consensus on relevant training, service, and ethical norms). The delegation of regulatory authority by government to a self-governing professional body hence requires a demonstration that self-regulation is more effective and/or less costly than direct regulation or perhaps regulation by a quasi-independent regulatory agency (analogous to, for example, the Ontario Energy Board or the Canadian Radio-television and Telecommunications Commission). Thus, a case needs to be established rather than assumed for professional selfregulation. ${ }^{37}$

As I and my co-authors, Carolyn J. Tuohy and Alan D. Wolfson, argued in an earlier review of professional regulation in Ontario:

Once a need for some form of regulation has been established, the case for professional self-regulation turns on four kinds of considerations: the costs of information, the costs of error, the costs of enforcement, and the establishment of trust.

Although there is great diversity in the activities of the different professions, there are common elements as well. In each case, we find the application of a body of knowledge that is systematic and sometimes arcane. This is a knowledge base which, by its nature, can be acquired only by long and arduous training. Second, the activities of the professions touch on some of the most fundamental of human affairs.... Third, professional practitioners are numerous and their clients are even more numerous. Professional services intrinsically involve the application of general knowledge to particular cases; they are, therefore, essentially individual in scope. Finally, the essence of the professional relationship involves the assumption of an agency role by the practitioner, acting on behalf of all relevant interests involved in the decision-making, the client's interests and those of third parties, and suppressing altogether his own interests. This agency function cannot be established and cannot be maintained in the absence of trust. Professionals must be trusted to act for their clients rather than for themselves, and they must be trusted to be sensitive to the interests of affected third parties. Without trust, professional relationships would flounder.

The choice between direct and self-regulation of quality in these professional markets is affected by these four characteristics. The determination that a service is of high quality or that a practitioner is adequately qualified can be made only by the application of the systematic knowledge base of the profession. If the state chooses to regulate the quality of professional services directly, it may, of course, hire "experts" [presumably from the profession in question] to assist it in its task. Clearly, however, the acquisition of this information is costly, even if it is facilitated by retaining expert advisors. The delegation of regulatory powers to the profession itself would place the responsibility for quality assurance in the hands of people who have sufficient knowledge to do the job.

The costs of error are also high. Since the activities of professionals are "important," the performance of poor quality services or, more generally, the certification or licensure of unqualified practitioners, constitutes a serious challenge to the public interest. In extreme cases, public health and safety may be imperiled. Even in less dramatic circumstances, the state cannot easily countenance "errors" made in quality assurance in these markets. Such errors will, of course, be more numerous when the regulator lacks the information

37 For an excellent review of challenges to the concept of self-regulation in Ontario, see Sophia Sperdakos, Policy Council, Law Society of Upper Canada, "Self-Regulation and the Independence of the Legal Profession in Ontario" May 2007. 
necessary to assess quality correctly. The combination of the high costs of acquiring such information and the high costs of doing without it appear to argue in favour of delegating the regulatory function to the profession itself.

There are further arguments supporting such a delegation. The fact that professional practitioners are so numerous, and that their services are so myriad, implies that enforcement of quality standards constitutes a formidable undertaking. The strong allegiances to the profession and its norms, developed [and internalized] by members as part of their education and training, serve to enhance voluntary compliance with quality standards. In this way the enforcement costs associated with monitoring and policing legions of practitioners can be substantially reduced by delegating this responsibility to the profession as a whole.

Finally ... trust relationships are extremely fragile, especially when they touch on matters of importance. But trust is fundamental to the professional's role; the professional "agent" cannot perform his function without this trust.... [I]ndividual clients and the public at-large are much more likely to have confidence in the activities of practitioners when the state has indicated its confidence in the profession as a whole. The delegation of regulatory authority to a self-governing body of the profession signals such a trust and thereby reinforces the establishment and maintenance of similar trust relationships at the individual level.

It is important to note that the delegation of regulatory authority is not itself without costs. There are risks that a self-regulating profession will not adequately discharge its responsibilities, particularly in the face of conflicts of interest that may arise. These are likely to be particularly pronounced in areas where the profession's economic interests are at stake, such as in the protection of a professional monopoly over rights to practise and in the discouragement of competitive practices among its members. ${ }^{38}$

An example of this tension is the protracted debates in Ontario (and other provinces) as to the roles and responsibilities of paralegals now to be formally regulated by the LSUC under the Access to Justice Act, 2006. ${ }^{39}$ This Act has amended the Law Society Act and created a Paralegal Standing Committee comprising five lawyer Benchers, five elected paralegals, and three lay Benchers responsible for developing bylaws governing the qualifications, roles, and responsibilities of paralegals, subject to approval by Convocation. ${ }^{40}$

This tension in turn raises complex issues in striking an appropriate balance between independence and accountability, which may raise special concerns in the case of the legal profession relative to other professions because lawyers often assume professional responsibility for representing clients with interests adverse to government (or the state). Thus, lawyers are vulnerable to recriminations or retribution through regulatory bodies over which government exercises any significant influence (a problem all too evident in many developing and authoritarian regimes). ${ }^{41}$

However, as Patrick Monahan points out in a research study for the recent LSUC's Task Force on the Rule of Law and the Independence of the Bar, the independence of the bar has

c. 21.

provision being s. 25.1 of the Law Society Act).

${ }_{41}$ See Michael Trebilcock \& Ron Daniels, Rule of Law Reform and Development: Charting the Fragile Path of Progress (Northhampton, Mass.: Edward Elgar, 2008), c. 9. 
both a narrower and a broader interpretation. ${ }^{42}$ The narrower interpretation refers to the freedom of individual lawyers to give advice to and represent clients without their independent advice or advocacy being constrained by improper external pressures (including inappropriate encroachments on solicitor-client confidentiality). ${ }^{43}$ The broader interpretation refers to the independence of the profession as a whole and its status as a self-governing profession. ${ }^{44}$ Monahan argues that there may well be other ways - not involving selfregulation - in which independence from government control can be protected. ${ }^{45}$ One option is a form of so-called "co-regulation," reflected in recent initiatives in the United Kingdom and several Australian states to create Legal Services Boards or Commissions with broad oversight powers over the self-regulatory functions of the organized legal profession, with a particular focus on providing an alternative or parallel avenue for investigating complaints against lawyers and imposing sanctions for misconduct. ${ }^{46}$

In my view, however, we should be very cautious in moving in the direction of a highly institutionalized form of so-called "co-regulation" of the legal profession. While absolute forms of self-regulation are difficult, if not impossible, to defend, other forms of accountability are feasible short of direct oversight by government or an agency that it appoints (in whole or in part), with all the risks that this entails of political interference in the fearless discharge of lawyers' responsibilities to their clients, through regulatory retribution, and of progressive "mission creep" once such an agency is created and seeks to justify its existence. In the past, in Canada, attempts to temper absolute forms of self-regulation of the legal profession have principally taken the form of the appointment (often by provincial Attorneys General) of a handful of non-lawyer citizens to the governing bodies of the legal profession (and some of its key committees, for example, discipline committees). This mechanism of accountability has often been deficient in at least two respects. First, the number of non-lawyer members so appointed has often been token. In Ontario, there are currently 40 elected Benchers, two paralegal Benchers appointed by the Attorney General, and eight lay Benchers appointed by the Lieutenant Governor-in-Council. ${ }^{47}$ Second, and more seriously, simply appointing more or less random "good citizens" to the governing body of the legal profession provides no clear definition of their mandate or responsibilities. Both factors lead to serious risks of co-option or marginalization of the non-lawyer members of governing bodies.

Instead, it is preferable to identify key organized non-lawyer constituencies affected by the provision of legal services and vest in them the responsibility for nominating representatives to the governing body of the legal profession. These representatives would

42 Patrick Monahan, "The Independence of the Bar as a Constitutional Principle in Canada" in Law Society of Upper Canada, In the Public Interest: The Report and Research Papers of the Law Society of Upper Canada's Task Force on the Rule of Law and the Independence of the Bar (Toronto: Law Society of Upper Canada, 2007).

43 Ibid.

$44 \quad$ Ibid.

$45 \quad$ Ibid.

$46 \quad$ See Pue, supra note 10 at 104-15; Richard F. Devlin \& Porter Heffernan, "The End(s) of SelfRegulation" (2008) 45:5 Alta. L. Rev. 169. These proposals are endorsed by Philip Slayton in his recent book on the Canadian legal profession, supra note 32 at 14-15, 238-39.

47 See "Management and Convocation," online: The Law Society of Upper Canada <http://www.lsuc. on.ca/about/a/management/>. 
then be held accountable for articulating the concerns of the constituency they represent and, at the limit, act as public "whistle-blowers" if they perceive regulatory policies or decisions of the governing body to be seriously at variance with the public interest. These constituencies would include: cognate professions, para-professionals, client interests (both commercial and household), and the poverty law community represented by the community boards of legal aid clinics. These representatives might well comprise around 25 percent of the membership of the governing body.

Beyond this, it is clear that a major impetus for recent forms of "co-regulation" in Britain and Australia are concerns (often well-founded) over the actual or perceived inability or unwillingness of self-governing bodies of the legal profession to deal assiduously and effectively with public complaints about the competence and integrity of individual lawyers with whom members of the public have had interactions. This, of course, underscores the importance of an active competence orientation, as outlined above. But wishing it were so will not make it so. Some easy moves are available. First, representatives of client interests (especially the most vulnerable household client sector) should sit on all disciplinary committees. Second, the legislature should require, as a condition of the grant of a substantial measure of regulatory autonomy, that the governing body of the legal profession make public an annual report that provides hard information and data on legislatively specified key issues, including trends on numbers and demographics of new members; policies instituted to avoid professional protectionism by recognizing credentials of out-of-province and foreign lawyers, and numbers of admittees in these categories and conditions attaching thereto; and the number of complaints against practising lawyers, classified by type of complaint and disposition thereof. There are probably other issues that bear directly on the public interest that could profitably be added to this list (and amplified over time). This might be complemented by a publicly available database where consumers can check on disciplinary investigations, complaints histories, etc., of individual lawyers.

A more difficult issue relates to whether complainants should have some other formal avenue of recourse if they lack confidence in the ability of law societies to investigate and dispose of complaints assiduously and objectively, or are aggrieved with the outcome of this process. This clearly lies at the heart of recent "co-regulation" initiatives in Britain and Australia. Before taking such a major step away from regulatory autonomy, two more modest steps are worthy of consideration: first, either expand the jurisdiction of general provincial Ombudsmen so as to encompass complaints about the exercise of delegated self-regulatory powers by the legal profession, with public mediation of these complaints and reporting on outcomes (as with other complaints) to the provincial legislature as the principal forms of response (already the case in British Columbia); alternatively, as was the case in Britain prior to the recent reforms, a special (perhaps non-lawyer) Ombudsman for the legal profession could be appointed to perform these functions.

\section{Conclusion}

The only defensible public policy rationale for regulation of the legal profession is a consumer protection, not a professional protectionist rationale. With respect to policy instruments for professional regulation, the legal profession should devote fewer of its regulatory resources and the regulatory compliance resources of its members to input 
regulation and devote a higher proportion of its resources to output regulation. Consumers ultimately are only interested in the quality of outputs, and are interested in the quality of inputs only insofar as they affect the quality of outputs. Traditionally, the legal profession, like many other professions, has principally relied upon a point-of-entry general licensure regime for quality control,. This regime, standing alone, is a frail reed for ensuring post-entry competence in all the areas in which licensed practitioners are likely to be active. However, the response to the frailties and limitations of a point-of-entry licensure regime should not be more input regulation, but instead a much enhanced focus on targeted and selective output regulation. This is the preferable choice even though in terms of the internal politics of the profession this may be a more painful choice than adding additional layers of generalized input regulation. Put simply, regulatory resources should be re-allocated from the front end to the back end of the quality assurance process. What matters most is whether the regulatory regime in question is generating a set of product or service qualities and costs that informed consumers would want. This calls for selective regulation (a scalpel, not a blunder-buss) that focuses on real problems and avoids imposing costs on the vast majority of those in the legal profession for whom competence is not a problem. These costs will inevitably be passed on to consumers of legal services with no off-setting benefits to them.

There are also substantial public virtues in self-regulation of the legal profession, but regulatory independence cannot be absolute and must be tempered with appropriate public accountability mechanisms. The precise nature of these mechanisms may define the frontiers of future public debates about the regulation of the legal profession in Canada. If the legal profession wishes to retain a substantial measure of regulatory autonomy (as it should), and avoid excessively intrusive public accountability mechanisms, it is incumbent on it to move pre-emptively and proactively so as to demonstrate sensitivity and responsiveness to legitimate public concerns about the quality of legal services. 